Argentina in the Global Middle East 
This page intentionally left blank 


\section{Argentina in the Global Middle East}

Lily Pearl Balloffet 
Stanford University Press

Stanford, California

(C) 2020 by the Board of Trustees of the Leland Stanford Junior University. All rights reserved.

No part of this book may be reproduced or transmitted in any form or by any means, electronic or mechanical, including photocopying and recording, or in any information storage or retrieval system without the prior written permission of Stanford University Press.

Printed in the United States of America on acid-free, archival-quality paper

Library of Congress Cataloging-in-Publication Data

Names: Balloffet, Lily Pearl, author.

Title: Argentina in the global Middle East / Lily Pearl Balloffet.

Description: Stanford : Stanford University Press, 2020. I Includes

bibliographical references and index.

Identifiers: LCCN 2020004592 (print) I LCCN 2020004593 (ebook) I ISBN

9781503611740 (cloth) I ISBN 9781503613010 (paperback) I ISBN

9781503613027 (ebook)

Subjects: LCSH: Arabs—Argentina-History. I Middle

Easterners-Argentina—History. I Immigrants—Argentina-Social

conditions. I Emigration and immigration-Social aspects. I

Argentina-Emigration and immigration-History. I Middle

East-Emigration and immigration-History.

Classification: LCC F3021.A59 B35 2020 (print) I LCC F3021.A59 (ebook) ।

DDC $982-\mathrm{dc} 23$

LC record available at https://lccn.loc.gov/2020004592

Cover design: Christian Fuenfhausen 
Por, y principalmente a causa de, Javier And for Julie, the ultimate detective. 
This page intentionally left blank 